\title{
Environmental Factors, Knowledge, and Hygiene Behaviour among Mothers: A Slum Area in Bandung City, West Java, Indonesia
}

\author{
Gusti Adintya Putri, ${ }^{1}$ Sri Yusnita Irda Sari, ${ }^{2}$ Yoni Fuadah Syukriani ${ }^{3}$ \\ ${ }^{1}$ Faculty of Medicine Universitas Padjadjaran, ${ }^{2}$ Department of Public Health Faculty of Medicine, \\ Universitas Padjadjaran, ${ }^{3}$ Department of Forensic and Legal Medicine Faculty of Medicine \\ Universitas Padjadjaran/Dr. Hasan Sadikin General Hospital, Bandung
}

\begin{abstract}
Background: The increased number of population living in urban areas causes the increase of requirement of basic life needs as well as the increase of household and human excreta waste. If these wastes were not well managed, this situation would contaminate the environment. This study aimed to analyze the relatioship between environmental factors, knowledge and hygiene behavior among mothers who lives in Bandung slum area.

Methods: An analytic cross sectional study was carried out on 132 mothers who lived in Tamansari subdistrict in Bandung city (RW 06, 07, 15, and 16) from May to October 2014. The primary data were collected using 2 sets of questionnaire and an observation checklist. The environmental factors and knowledge variables were catagorized into good and poor, while hygiene behavior was catagorized into good, moderate, and poor. The collected data were statistically analyzed using Chi-Square test.

Results: More than half of the participants had good environmental factors (60.6\%), 59 participants $(44.6 \%)$ had good knowledge about hygiene and 83 participants $(62.9 \%)$ had good hygiene behavior, 43 participants $(32.6 \%)$ had a moderate hygiene behavior, and 6 participants $(4.5 \%)$ bad hygiene behavior. Environmental factors was related to hygiene behavior $(\mathrm{p}=0.002)$. However, knowledge was not related to hygiene behavior $(\mathrm{p}=0.539)$.
\end{abstract}

Conclusions: Environment is a significant factor to hygiene behavior.

Keywords: Environmental factors, hygiene behavior, knowledge, slum area

\section{Introduction}

The trend of human's habitat has shifted in the last few decades. According to the Population Division of the United Nations, since 2009, the number of people who lived in city areas have exceeded the number of people who lived in rural areas. ${ }^{1}$ This urbanization phenomenon occurred in every country in the world, including in the developing countries such as Indonesia. ${ }^{1}$

The population growth rate would be parallel with the increasing demand for basic life needs such as living space. More people were likely to live in a poor environmental setting, such as a slum area. Moreover, this condition would also affect the increase of house waste and human excreta waste production, which if not well-managed would contaminate the environment.

Furthermore, the contaminated environment will increase the risk of people getting diseases. Hygiene behavior would become one of the key aspects on preventing diseases. According to Fishbein, et al. ${ }^{2}$, there are several aspects such as knowledge and skills, salience of the behavior, intention to perform, environmental factors, and a habit which is known as the determinant of a person to perform a behaviour, as described in the Integrated Behavioral Model (IBM) theory. ${ }^{2}$

Bandung is one of Indonesia's urban areas. The "Health profile of Bandung" year 2012 reported that the population growth rate was $1.25 \% .^{3}$ Bandung also experiences a positive net migration, meaning, a higher number of people migrated to the city. ${ }^{4}$ Tamansari is one of the slum areas with the highest population density in Bandung Wetan district (9,889/ $\mathrm{km}^{2}$ ), and located in the centre of the city along Cikapundung river. ${ }^{4}$ The aim of this study was to analyze the relationship between environmental factor, knowledge and hygiene behavior among mothers in Tamansari

Correspondence: Gusti Adintya Putri, Faculty of Medicine, Universitas Padjadjaran, Jalan Raya Bandung-Sumedang Km.21, Jatinangor, Sumedang, Indonesia, Email: gustiadintya@yahoo.co.id 
subdistrict, Bandung.

\section{Methods}

This was an observational analytic cross sectional study. The study was conducted in Tamansari subdistrict, Bandung Wetan, Bandung, from May to October 2014. The sample of the study was mothers who lived in Rukun Warga (RW) 06, 07, 15, and 16, Tamansari subdistrict. The areas were selected because those areas were the most densely populated and closest area to Cikapundung river. The minimum sample required in the study was 97 participants. Samples were obtained using systematic random sampling. There were 142 home visits but only 132 participants gave complete information, and were included in the data analysis.

Primary data was collected by using two sets of questionnaire and one observation checklist. The questionnaire about environmental factors which was used in this study were obtained from World Health Organization-United Nation Children's Fund (WHO-Unicef) core question on drinkingwater and sanitation for household survey. ${ }^{5}$ Accounted aspects included: type of toilet used, disposal of diapers, availability of trash, garbage disposal, clean water and drinking water source, waste disposal of human excreta, the availability of a septic tank in the neighborhood, and pets. Every aspect was given a score of 1 for improved and 0 for unimproved answers. Then the scores were accumulated and categorized either good $(>$ mean) or poor $(<$ mean).

The level of knowledge of the participants was assessed by an interview with questions adopted from a publication by Stevenson et al. ${ }^{6}$ The questionnaire consisted of 5 subcategories: general cleanliness (5 questions), household hygiene (2 questions), food hygiene (3 questions), hand hygiene (2 questions), and personal hygiene (3 questions). For each correct answer was given a score of 1 and for every wrong answer or 'do not know' was given a score of 0 . The scores then were accumulated and categorized either good ( $>$ mean) or poor $(<$ mean). It was validated to 26 respondents prior to the study.

Furthermore, the hygiene behavior of the participants was assessed with the observation of Hygiene Index, as written by Webb et al. ${ }^{7}$ The subcategories were: drinking water hygiene ( 3 indicators), food hygiene ( 3 indicators), personal hygiene (3 indicators), and household hygiene (6 indicators). For every good behavior was given a score of 1 and for any bad behavior was given a score of 0 . The scores then were accumulated and categorized as good (10-15), moderate (69 ), and poor (0-5). The ethical protocol has been approved by the Health Research Ethics Committee, Faculty of Medicine Universitas Padjadjaran, Ethical Exemption No. 449/UN6. C2.1.2/KEK/PN/2014.

The data was analyzed using statistical application. Then, the chi square method was performed to determine the relationship between each categorical variable. The relationship would be considered significant if $\mathrm{p}<0.05$.

\section{Results}

The characteristics distribution of respondents in this study showed that the age of the respondents ranged from 20 years to 77 years with a median age of 42 years. A total of 51 respondents $(38.6 \%)$ were high school graduates or equivalent, and most respondents had moderate-low income each month, ranging from $\mathrm{Rp} 500,001$ to $\mathrm{Rp} 1,500,000$. The number of people living in one house varied between one and twenty people. The majority of respondents had one to five people who lived in their houses $(69.2 \%)$ (Table 1$)$.

Based on environmental factors and level of knowledge, this study discovered that more than half of the respondents had good environmental factors, but the majority of the respondents had a poor level of knowledge about hygiene (Table 2).

Moreover, all respondents used an unimproved toilet $(100 \%)$. A total of 107 $(81 \%)$ of them had a flush toilet while the other $25(19 \%)$ did not have a flushing toilet. Out of 40 respondents who had children under the age of 3 years, 22 of them (55\%) disposed of diapers in a way that was considered good. Most respondents had a trash bin in the house and most of them $(93.1 \%)$ collected the trash to a temporary domestic waste disposal nearby. A total of 130 respondents (98.4\%) used a clean water source that was considered good, and the same number of respondents used drinking water sources which was categorized as good.

No respondents used septic tanks as disposal of human waste, in other words, no septic tank was available in the surrounding area of the survey. A total of 42 respondents $(31.8 \%)$ had pets in the house and 36 of them $(85.7 \%)$ used a cage either inside or outside the house. In the observation of water storage, 
Table 1 Characteristics Distribution of the Respondents

\begin{tabular}{|c|c|c|}
\hline Variable & Frequency (f) & Percentage (\%) \\
\hline \multicolumn{3}{|l|}{ Age } \\
\hline 20-29 years & 12 & 9.1 \\
\hline $30-39$ years & 38 & 28.8 \\
\hline $40-49$ years & 37 & 28 \\
\hline 50-59 years & 31 & 23.5 \\
\hline$>60$ years & 14 & 10.6 \\
\hline \multicolumn{3}{|l|}{ Occupation } \\
\hline Housewife & 103 & 78.2 \\
\hline Sales & 21 & 15.9 \\
\hline Teacher & 3 & 2.2 \\
\hline Employee & 2 & 1.5 \\
\hline Pension & 3 & 2.2 \\
\hline \multicolumn{3}{|l|}{ Education } \\
\hline Elementary & 37 & 28 \\
\hline Junior high & 29 & 21.9 \\
\hline Senior high & 51 & 38.6 \\
\hline Diploma & 6 & 4.5 \\
\hline Bachelor & 9 & 6.8 \\
\hline \multicolumn{3}{|l|}{ Monthly Income (Rupiahs) } \\
\hline$<500.000$ & 3 & 2.3 \\
\hline $500.001-1.500 .000$ & 75 & 56.8 \\
\hline $1.500 .001-3.000 .000$ & 46 & 34.8 \\
\hline$>3.000 .000$ & 8 & 6.1 \\
\hline \multicolumn{3}{|c|}{ Number of people live in the house } \\
\hline 1-5 people & 92 & 69.2 \\
\hline 6-10 people & 35 & 26.5 \\
\hline 11-15 people & 3 & 2.3 \\
\hline 16-20 people & 2 & 1.5 \\
\hline
\end{tabular}

as many as 83 respondents (62.9\%) left water in a container or bucket with the risk of contamination, and as many as 76 respondents $(57.6 \%)$ kept their water storage near the source of pollutants.

All respondents learned about the necessity of washing hands after going out and after touching animals (100\%). Most of the respondents (90.2\%) saw the need of washing hands before eating, and a number of 125 respondents $(94.7 \%)$ knew the need for washing hand after defecation. A total of 127 respondents $(96.2 \%)$ realised the need to brush their teeth at least twice a day.

Additionally, in the aspect of household hygiene, most respondents knew that the bathroom and toilet should be cleaned at least once a week $(75.8 \%)$ and the house needs to be swept at least once a day $(76.5 \%)$. In the food hygiene aspects, 130 respondents (98.5\%) were able answer questions correctly regarding the need to wash hands before making meals, 121 respondents (91.7\%) were aware that vegetables should be washed before eating, and 124 respondents (93.9 $\%$ ) agreed the need of water to be boiled or filtered before drinking.

Furthermore, most of the respondents were able to answer correctly the question of knowledge on aspects of hand hygiene and 
Table 2 Distribution of Environmental Factors and Level of Knowledge

\begin{tabular}{|c|c|c|c|c|c|c|}
\hline \multirow{2}{*}{ Characteristics } & \multicolumn{2}{|c|}{$\begin{array}{c}\text { Environmental } \\
\text { factors }\end{array}$} & \multirow{2}{*}{ p value } & \multicolumn{2}{|c|}{ Hygiene knowledge } & \multirow{2}{*}{ p value } \\
\hline & $\begin{array}{c}\text { Good } \\
(n=80)\end{array}$ & $\begin{array}{l}\text { Poor } \\
(n=52)\end{array}$ & & $\begin{array}{c}\text { Good } \\
(n=59)\end{array}$ & $\begin{array}{l}\text { Poor } \\
(n=73)\end{array}$ & \\
\hline Age & & & 0.340 & & & 0.522 \\
\hline $20-29$ years & 6 & 6 & & 5 & 5 & \\
\hline 30-39 years & 22 & 16 & & 10 & 10 & \\
\hline $40-49$ years & 25 & 12 & & 16 & 16 & \\
\hline 50-59 years & 16 & 15 & & 9 & 9 & \\
\hline$>60$ years & 11 & 3 & & 4 & 4 & \\
\hline Occupation & & & 0.121 & & & 0.976 \\
\hline Housewife & 57 & 46 & & 35 & 68 & \\
\hline Sales & 17 & 4 & & 6 & 15 & \\
\hline Teacher & 2 & 1 & & 1 & 2 & \\
\hline Employee & 2 & 0 & & 1 & 1 & \\
\hline Pension & 2 & 1 & & 1 & 2 & \\
\hline Education & & & 0.145 & & & 0.246 \\
\hline Elementary & 18 & 19 & & 10 & 27 & \\
\hline Junior high & 16 & 13 & & 9 & 20 & \\
\hline Senior high & 36 & 14 & & 16 & 34 & \\
\hline Diploma & 3 & 3 & & 4 & 2 & \\
\hline Bachelor & 7 & 2 & & 5 & 4 & \\
\hline Monthly Income & & & 0.910 & & & 0.046 \\
\hline$<500.000$ & 2 & 1 & & 1 & 2 & \\
\hline $500.001-1.500 .000$ & 45 & 30 & & 18 & 57 & \\
\hline $1.500 .001-3.000 .000$ & 29 & 17 & & 20 & 26 & \\
\hline$>3.000 .000$ & 4 & 4 & & 5 & 3 & \\
\hline Number of people live in the house & & & 0.390 & & & 0.421 \\
\hline 1-5 people & 55 & 37 & & 32 & 60 & \\
\hline 6-10 people & 22 & 13 & & 11 & 24 & \\
\hline 11-15 people & 1 & 2 & & 0 & 3 & \\
\hline 16-20 people & 2 & 0 & & 1 & 1 & \\
\hline
\end{tabular}

personal hygiene. All respondents knew the correct hand washing must use clean water and soap $(\mathrm{n}=132,100 \%)$ and as many as 104 respondents $(78.8 \%)$ realized the need for drying hands after washing. Most respondents confirmed the need to shower three times a day. Most of the respondents knew that the worn clothes needed to be changed at least once in more than two days and almost all respondents knew that underwear should be changed every day.

Based on observation of hygiene behavior, more than half of the respondents had a good hygiene behavior (Table 3).

Most respondents stored drinking water in sealed containers (95.5\%), clean on the outside $(89.4 \%)$, and filled with water at the time of observation (94.7\%). A total of 56 respondents (42.4\%) kept clean dishes covered, 90 respondents (68.2\%) kept clean dishes at high altitudes, and as many as 66 respondents (50\%) left all the food covered. A total of 47 respondents (36.5\%) used footwear, the hands of 110 respondents (83.3\%) were 
Table 3 Distribution of Hygiene Behavior

\begin{tabular}{|c|c|c|c|c|}
\hline \multirow[b]{2}{*}{ Characteristics } & \multicolumn{3}{|c|}{ Hygiene behavior } & \multirow[b]{2}{*}{ p value } \\
\hline & $\begin{array}{c}\text { Good } \\
(n=83)\end{array}$ & $\begin{array}{c}\text { Moderate } \\
(n=43)\end{array}$ & $\begin{array}{l}\text { Poor } \\
(n=6)\end{array}$ & \\
\hline Age & & & & 0.735 \\
\hline 20-29 years & 8 & 3 & 1 & \\
\hline 30-39 years & 25 & 12 & 1 & \\
\hline 40-49 years & 20 & 14 & 3 & \\
\hline $50-59$ years & 19 & 11 & 1 & \\
\hline$>60$ years & 11 & 3 & 0 & \\
\hline Occupation & & & & 0.764 \\
\hline Housewife & 64 & 35 & 4 & \\
\hline Sales & 15 & 4 & 2 & \\
\hline Teacher & 1 & 2 & 0 & \\
\hline Employee & 1 & 1 & 0 & \\
\hline Pension & 2 & 1 & 0 & \\
\hline Education & & & & 0.432 \\
\hline Elementary & 22 & 12 & 3 & \\
\hline Junior high & 16 & 11 & 2 & \\
\hline Senior high & 36 & 13 & 1 & \\
\hline Diploma & 3 & 4 & 0 & \\
\hline Bachelor & 6 & 3 & 0 & \\
\hline Monthly Income & & & & 0.562 \\
\hline$<500.000$ & 3 & 0 & 0 & \\
\hline 500.001-1.500.000 & 47 & 25 & 3 & \\
\hline $1.500 .001-3.000 .000$ & 29 & 14 & 3 & \\
\hline$>3.000 .000$ & 4 & 4 & 0 & \\
\hline Number of people live in the house & & & & 0.787 \\
\hline 1-5 people & 55 & 32 & 5 & \\
\hline 6-10 people & 24 & 10 & 1 & \\
\hline 11-15 people & 2 & 1 & 0 & \\
\hline 16-20 people & 2 & 0 & 0 & \\
\hline
\end{tabular}

clean, and the index finger of 72 children $(54.5 \%)$ were also clean.

In the household hygiene, there were 89 homes of respondents (67.4\%) with no garbage scattered outside the home, and 74 homes of the respondents $(56.1 \%)$ had no garbage strewn in the house. In addition, 106 $(80.3 \%)$ of respondents did not let animals roam in the house or patio, 72 respondents $(54.5 \%)$ did not keep a pile of dirty clothes. There were no flies in a significant number of houses $(81.1 \%$, and among 88 houses $(66.7 \%)$ there was not any puddle with no patio or around the house.

Based on environmental factors and knowledge of the respondents regarding hygiene behavior, there was a significant difference between respondents who had good and bad environmental factors. This study discovered that there was a statistical difference between environmental factors and hygiene behavior $(p=0.002)$. However, there were no statistical differences between respondents with knowledge of good and bad and hygiene behaviour $(\mathrm{p}=0.539)$ (Table 4). 
Table 4 Environmental Factor and Hygiene Knowledge Regarding Hygiene Behavior

\begin{tabular}{|c|c|c|c|c|c|}
\hline \multirow[b]{2}{*}{ Variable } & \multicolumn{3}{|c|}{ Hygiene behavior } & \multirow{2}{*}{$\begin{array}{l}\text { Total } \\
\text { n (\%) }\end{array}$} & \multirow[b]{2}{*}{$\mathbf{p}$} \\
\hline & $\begin{array}{c}\text { Good } \\
(n=83)\end{array}$ & $\begin{array}{c}\text { Moderate } \\
(n=43)\end{array}$ & $\begin{array}{l}\text { Poor } \\
(n=6)\end{array}$ & & \\
\hline \multicolumn{6}{|l|}{ Environmental factor } \\
\hline Good & $60(70 \%)$ & $18(22.5 \%)$ & $2(2.5 \%)$ & $114(100 \%)$ & 0.002 \\
\hline Poor & $23(44.2 \%)$ & $25(48.1 \%)$ & $4(7.7 \%)$ & $18(100 \%)$ & \\
\hline \multicolumn{6}{|l|}{ Knowledge } \\
\hline Good & $36(61 \%)$ & $19(32.2 \%)$ & $4(6.8 \%)$ & $59(100 \%)$ & 0.539 \\
\hline Poor & $47(64.4 \%)$ & $24(32.9 \%)$ & $2(2.7 \%)$ & $73(100 \%)$ & \\
\hline
\end{tabular}

\section{Discussions}

The rising population living in urban slums was clearly demonstrated in this study, one third of the respondents lived with more than five people in one house. Moreover, there were five household with more than ten people in the house. The population density caused by urbanization was also found in several other countries in the world such as in Kenya, India, Bangladesh, the Philippines, and other developing countries. ${ }^{8-11}$ Overly dense residential neighborhoods and inadequate housing conditions can increase the risk factor of some diseases, such as respiratory infectious diseases, diarrhea, cancer, to developmental disorders in children. ${ }^{12-15}$ Thus, the population density in the area is in need of concern of local stakeholders, in order to protect the community health.

More than half of the respondents, 83 people (62.8\%), had a good level of hygiene behaviors. This could be caused by the educational background of the respondents who were mostly high school graduates. However, on a higher level of knowledge, the majority of the respondents were still on the poor level (55.3\%). This was not in line with the study by Ahuja et al. ${ }^{16}$, in Mumbai, India, where respondents with higher education were able to answer questions about knowledge better.

Among all respondents who participated in the study, none of them had a septic tank in the human waste disposal system. Absence of septic tanks could also contaminate the water sources in the neighborhood, where $66.7 \%$ of respondents used well-water as source of clean water as well as source of drinking water for 46 respondents (34.8\%). A study in Langa ${ }^{17}$, a slum area in Kenya, discovered that most of the faecal contamination of water sources did not meet the criteria of the WHO drinking water quality due to sanitation in the environment are inadequate.

Afurther study must be conducted on the water content in the local area to confirm water quality concerns, as water pollution can cause the transmission of infectious diseases such as fecal-oral cholera, typhoid, hepatitis, polio, and ascariasis. ${ }^{18-19}$ The management of human sewage in the local area needs to be improved to reduce the risk of disease.

Furthermore, economic limitations might be another consideration for urban slum communities to choose boiling water for drinking instead of buying bottled water. Most respondents had moderate-low incomes per month, Rp500,001.00 up to Rp1,500,000.00. Consistently, more respondents used cooking water from water wells and water taps for drinking water. This was parallel with the study conducted by Alam, et al. ${ }^{20}$ in urban slums in Rajshashi, Bangladesh.

Results of this study revealed that some of the respondents were raising pets without cages and some of the respondents let their pets roam in and around the house. On the other hand, pets can be an intermediary source for infection either by bacteria in the body and through the dirt when contaminating water and food consumed. ${ }^{18}$ The community needs to be educated about the importance of pet hygiene to prevent transmission of disease through vaccination of pets and animals.

This study discovered, there was no significant difference of hygiene behavior between respondents who had a good level of knowledge and poor level of knowledge. The results were less in accordance with the theory of IBM, which states that the level of knowledge is a factor that determines the behavior of individual hygiene. ${ }^{2}$ There were other factors such as intentions, habits, and skills which also determined the behavior of individuals that were not involved in this 
research.

In conclusion, environmental factors of the respondents based on hygiene behavior show a significant difference between respondents who have good and poor environmental factors. The findings are consistent with the theory of IBM, which states the environment as a determining factor of individual hygiene behavior. $^{2}$ The limitation of the study was the absence of age definition of the respondent, which caused a large wide range (20-77 years old).

\section{References}

1. World Urbanization Prospects: The 2011 Revision. Population Division of the Department of Economic and Social Affairs of the United Nations Secretariat. [Internet Database] 2011 [cited 2012 February 8]. Available from: http://data.worldbank. org/

2. Glanz K, Rimer B, Viswanath $\mathrm{K}$, editor. Health behavior and health education: theory, research, and practice. 4 ed. San Fransisco. CA: Jossey-Bass; 2008.

3. Dinas Kesehatan Kota Bandung. Profil kesehatan Kota Bandung. Bandung: Dinas Kesehatan Kota Bandung; 2013.

4. Puskesmas Salam. Jumlah penduduk miskin di wilayah kerja UPT Puskesmas Salam. Bandung: Puskesmas Salam; 2012.

5. WHO. Core questions on drinking-water and sanitation for household survey. Switzerland: World Health Organization; 2006.

6. Stevenson RJ, Case TI, Hodgson D, PorzigDrummond R, Barouei J, Oaten MJ. A scale for measuring hygiene behavior: development, reliability and validity. Am J Infect Control. 2009;37(7):557-64.

7. Webb AL, Stein AD, Ramakrishnan U, HertzbergVS,Urizar M, MartorellR.Asimple index to measure hygiene behaviours. Int J Epidemiol. 2006;35(6):1469-7.

8. Cohen B. Urbanization in developing countries: current trends, future projections, and key challenges for sustainability. Technology in society. 2006;28(1):63-80.

9. Agbola T, Agunbiande EM. Urbanization, slum development, and security of tenure: the challenges of meeting millenium development goal (MDG) in 7 metropolitan Lagos, Nigeria. Committee for International Cooperation in National Research in Demography [Online Journal] 2007 [cited 2014 November 16]. Available from http://www.cicred.org/

10. Firdaus G. Urbanization, emerging slums and increasing health problems: a challenge before the nation: an empirical study with reference to state of uttar pradesh in India. J Environ Res Develop. 2012;3(9):0146-52.

11. Ooi GL, Phua KH. Urbanization and slum formation. J Urban Health. 2007;84(1):127-34.

12. Breysse P, Farr N, Galke W, Lanphear B, Morley R, Bergofsky L. The relationship between housing and health: children at risk. Environ Health Perspect. 2004;112(15):1583-8.

13. Thomson H, Petticrew M. Housing and health. BMJ. 2007;334(7591):434-5.

14. Vlahov D, Freudenberg N, Proietti F, Ompad D, Quinn A, Nandi V, et al. Urban as a determinant of health. J Urban Health. 2007;84(1):16-26.

15. Riley LW, Ko AI, Unger A, Reis MG. Slum health: diseases of neglected populations. $\mathrm{BMC}$ international health and human rights [Online Journal] 2007 [cited 2015 January 22]. Available from: http://biomedcentral. com/

16. Ahuja S, Chakrabakti N. To determine the level of knowledge regarding breast cancer and to increase awareness about breast cancer screening practices among a Group of women in a tertiary care hospital in Mumbai, India. Internet Journal of Public Health. 2010;1(1):1-19

17. Kimani-Murage EW, Ngincu AM. Quality of water the slum dwellers use: the case of a Kenyan slum. J Urban Health. 2007;84(6):829-38.

18. Prüss-Ustün $A B J$, Clasen $T$, Colford JM Jr, Cumming $\mathrm{O}$, Curtis V, Bonjour S, et al. Burden of disease from inadequate water, sanitation and hygiene in low- and middleincome settings: a retrospective analysis of data from 145 countries. Trop Med Int Health. 2014;19(8):894-905.

19. Ziegelbauer K, Speich B, Mäusezahl D, Bos $\mathrm{R}$, Keiser J, Utzinger J. Effect of sanitation on soil-transmitted helminth infection: systematic review and meta-analysis. PLoS medicine [Online Journal] 2012 [cited 2015 January 22] Avaliable from: http:// journals.plos.org/

20. Alam Z, Rahman A, Firoz AA. Water supply and sanitation facilities in urban slums: a case study of Rajshahi City corporation slums. American Journal of Civil Engineering and Architecture. 2013;1(1):1-6. 